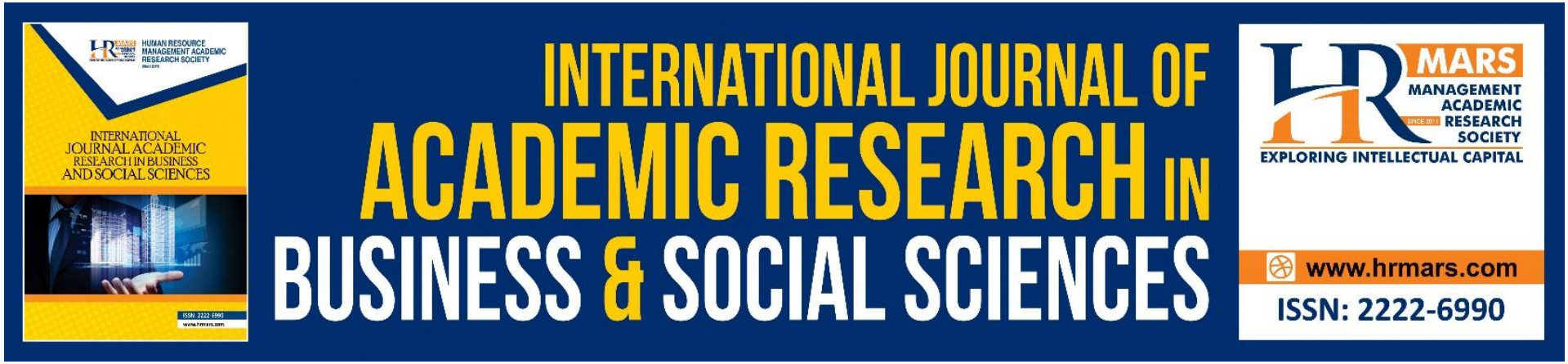

\title{
A Systematic Review of Youth Online Learning in ASEAN Countries
}

Intan Syafinaz Mat Shafie, Amily Fikry, Muhammad Iskandar Hamzah, Siti Fatahiyah Mahamood, Didin Hadi Saputra, M. M

To Link this Article: http://dx.doi.org/10.6007/IJARBSS/v11-i8/10771

DOI:10.6007/IJARBSS/v11-i8/10771

Received: 08 June 2021, Revised: 30 June 2021, Accepted: 20 July 2021

Published Online: 12 August 2021

In-Text Citation: (Shafie et al., 2021)

To Cite this Article: Shafie, I. S. M., Fikry, A., Hamzah, M. I., Mahamood, S. F., \& Didin Hadi Saputra, M. M. (2021). A Systematic Review of Youth Online Learning in ASEAN Countries. International Journal of Academic Research in Business and Social Sciences, 11(8), 706-725.

Copyright: (c) 2021 The Author(s)

Published by Human Resource Management Academic Research Society (www.hrmars.com)

This article is published under the Creative Commons Attribution (CC BY 4.0) license. Anyone may reproduce, distribute, translate and create derivative works of this article (for both commercial and non-commercial purposes), subject to full attribution to the original publication and authors. The full terms of this license may be seen at: http://creativecommons.org/licences/by/4.0/legalcode

Vol. 11, No. 8, 2021, Pg. 706 - 725

Full Terms \& Conditions of access and use can be found at http://hrmars.com/index.php/pages/detail/publication-ethics 


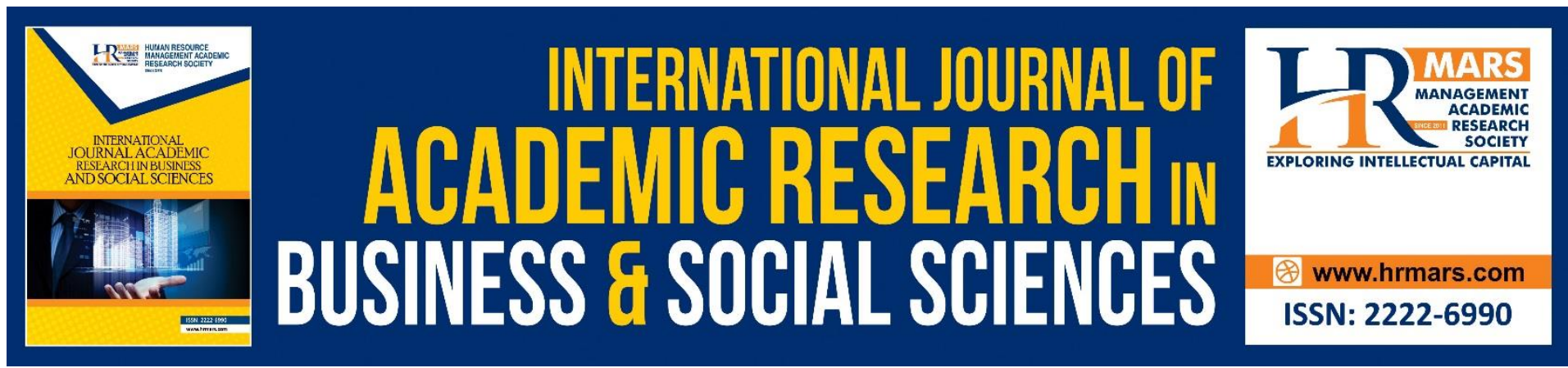

\title{
A Systematic Review of Youth Online Learning in ASEAN Countries
}

\author{
Intan Syafinaz Mat Shafie ${ }^{1}$, Amily Fikry², Muhammad Iskandar \\ Hamzah $^{3}$, Siti Fatahiyah Mahamood ${ }^{4}$, Didin Hadi Saputra, M. \\ $\mathrm{M}^{5}$
}

1,2 \&3 Faculty of Business and Management, Universiti Teknologi, MARA, Selangor Branch, Puncak Alam Campus, Malaysia, ${ }^{4}$ Academy of Contemporary Islamic Studies, Universiti Teknologi MARA, Shah Alam, Selangor, Malaysia, ${ }^{5}$ Public Administration Department, University of Nahdatul Wathan Mataram, Indonesia

Email: amily@uitm.edu.my

\begin{abstract}
Quality in higher education is one of the key enablers for developing nations to achieve their sustainable development goals by 2023. Recently, the Covid-19 pandemic forces university students to shift from traditional face-to-face to remote learning. Regardless of how classes are conducted, it is critical that the learning process is delivered according to the curriculum. The original goal of online learning is to allow students to learn whenever and wherever they want, at their own pace. Nevertheless, there appears to be a disparity in the rate of expansion of online learning between the West and developing countries particularly in the technology adoption, yet no matter what it takes, youth students in the world need to adapt to the new learning norm due to pandemic Covid 19. However, there are some drawbacks in online learning. Online learning limits the interaction between educators and other students in class industry observers have forecasted that the adoption of online learning in developing countries will grow faster in the next ten years. Noting that, past researchers putting effort to cover on empirical study. Yet, efforts to systematically review these promising area are still lacking. Thus, this article aims to fill the gap in understanding and identifying factors affecting youth online learning in ASEAN countries. Guided by the PRISMA Statement (Preferred Reporting Items for Systematic reviews and Meta-Analyses) review method, a systematic review of the Scopus and Web of Science databases identified 11 related studies. The systematic review process involved four (4) main processes, namely identification, screening, eligibility and data analysis. From 576 articles have been reviewed; only 11 articles were finally selected for further analyses. Further review of these articles resulted in three main themes - preferences of online learning tools, youth opinion on online learning and youth motivation on online learning in the ASEAN perspective. With in-depth deliberation, this paper provides several recommendations which are highlighted at the end of this article. Based on the review, it was found that several online learning tools are being preferred to be used by youth students in ASEAN countries namely, social networking sites,
\end{abstract}


entertainment video and websites, and multiplayer online role-playing game. Youth believed that online learning solely is insufficient in improving their academic performance and make them become more competent. This research only covered on youth online learning in ASEAN countries. There are many loopholes in this research that remain uncovered, future qualitative researchers may conduct systematic or umbrella review, or even conduct personal interview or focus group with teachers, instructors and facilitators as well, which may provide different insights and perspectives.

Keywords: Youth, Systematic Review, Online Learning, Pandemic, Covid 19, Database

\section{Introduction}

Quality in higher education is one of the key enablers for developing nations to achieve their sustainable development goals by 2023. Recently, the Covid-19 pandemic forces university students to shift from traditional face-to-face to remote learning. Regardless of how classes are conducted, it is critical that the learning process is delivered according to the curriculum. The original goal of online learning is to allow students to learn whenever and wherever they want, at their own pace. Nevertheless. there appears to be a disparity in the rate of expansion of online learning between the West and developing countries (Florea, 2010). In 2016, there were over 6 million students in the U.S. enrolled in at least one online course (Lederman, 2018; Babson Survey Research Group, 2014). Although appeared to be lagging, industry observers have forecasted that the adoption of online learning in developing countries such as Malaysia, Mexico, India, Thailand, Singapore, South Korea, Taiwan, Brazil and Eastern Europe countries will grow faster in the next ten years. Nonetheless, the pandemic has compelled students in these developing nations, particularly those with limited access to medical facilities and low vaccination rates, to embrace online learning for a prolonged period of time.

Online learning can be defined as learning experienced through the internet/onlinecomputers in a synchronous classroom where students interact with instructors and other students and are not dependent on their physical location for participating in this online learning experience (Singh \& Turman, 2019). The online learning delivery covers both asynchronous forms of interaction such as assessment tools and the provision of web-based course materials and synchronous interaction through email, newsgroups and conferencing tools, such as chat groups. (Curtain, 2002). Learning activities are synchronous when they allow learners to have a level of interactive at the same moment of time (Mason \& Rennie, 2006). The tools that may be used include video conferencing, Google Meet, WhatsApp, Telegram, Facebook Live Streaming and Microsoft Team. Asynchronous learning is online learning that takes place without real time situation. Learning activities do not occur at the same time with students or at the same place. The tools that may be used include video, blogs, email, file transfer and world wide web. Canvas and Moodle are hottest learning management systems that are becoming widely used by universities in developed countries in USA (Study International, 2020). Meanwhile, other countries are comfortable using television in online learning. Television has been utilized successfully as a mechanism for reaching out-of-school youth in a number of countries, particularly in Latin America and China, hence the results of such projects have been widely disseminated (Michael, 2005).

However, there are some drawbacks in online learning. Taking on the online classes additionally implies that the interruptions of the web are just before their eyes. They are 
always distracted by the environment in the home, not to mention to have shared space and computers with siblings or parents. Online learning does limit the interaction between educators and other students in class. The transition from face-to-face to online removed the opportunity to learn from other students, and breaking into smaller groups or commenting on each other's writing was no substitute for the real thing (Herman, 2020).

In some other cases, online learning has affected the mental health conditions of their wellbeing. Many students are suffering from stress and anxiety (Cao et al., 2020; Islam et.al., 2020). This situation hinders students from doing well during online learning. Though, online learning has changed the paradigm of learning among youth it also signifies the drawback in this area. A case study conducted by Dewantoro \& Rachmawati (2020) stated that a result of the high workload, many students feel frustrated and stressed by a large number of online recovery workloads. They felt at disadvantage in gaining workload done. Additionally, the workload of students in online lectures increases due to the higher time, costs, anxiety and fatigue levels than in face-to-face lectures (Didin et al., 2020).

Nevertheless, students' interaction with educators has changed into new shape. With online learning youth in higher education institutions are engaging students more and more through text messaging and nurturing of one-to-one relationships. Students are more motivated with this closeness of relationship where they are able to obtain focus treatment from the educators. Increased happiness was also reported by Chou and Hsiao (2000) as well as Morahan-Martin \& Shumaker (2013). There appears to be a general agreement that both teachers and students feel ICT use greatly pays to student motivation for learning. According to Voices of Youth (2019), with online learning they are able to arrange their learning schedule according to their preferences and be more responsible for their own success.

\section{Youth Online Learning in ASEAN Countries}

In human life, there are stages of life cycles. It begins as early as in foetus, baby, child, adolescent, adult and old person. Adolescents are also called teenager stage. In this stage it is also categorized under early adulthood which is known as youth. Thus, according to the United Nations (1981), for statistical purposes, it defines 'youth', as those persons between the ages of 15 and 24 years, without prejudice to other definitions by Member States. This issupported by WHO (2021) that defines 'adolescents' as individuals in the 10-19 years age group and 'youth' as the 15-24 years age group, while 'young people' covers the age range of 10-24 years.

Zooming to the ASEAN countries, the new landscape of learning also affected these countries to move from traditional teaching to online learning. The Association of Southeast Asian Nations (ASEAN) comprises Brunei, Cambodia, Indonesia, Laos, Malaysia, Myanmar, the Philippines, Singapore, Thailand, and Vietnam. Some of the members in this union are labelled as developed country such as Singapore, where the others are still categorized under developing countries. Even though Malaysia has over $80 \%$ Internet penetration, the infrastructure gap between West and East Malaysia is huge (Jalli, 2020). A better speed limit enjoys for those who are residing in West Malaysia. A proactive precaution in online learning taken by Thailand government. In Thailand, the use of blended teaching and face to face was employed by Mahidol University based on the nature of programmes and in line with procedures to prevent and control the spread of COVID-19 (Mahaisavariya, 2020). As noted 
above, most of the higher learning institutions in Singapore are embracing technologyenhanced learning way before the current pandemic. (Sia \& Adamu 2020). In contrary, lesser situation happens in Cambodia. In Cambodia, the percentage of internet users is still low compared to other countries in ASEAN, Kemp, (2015) reflects the Information and Technology (ICT) field in this country. Thus, difficulty occurs to spread online learning throughout the nation. According to Sia \& Adamu (2020), online learning has brought significant challenges to students. Promoting students' engagement through active learning can be a huge obstacle as online learning limits group discussion integration during the online class.

According to Statista Research Department (2020), a survey among ASEAN youths, 52.4 percent of respondents in Vietnam assessed that their current education and skills will need to be constantly updated. With online learning they faced challenges to keep motivated and updated. Lacking in digital knowledge and skills as well as unavailability of good internet accessibility added more factors to the challenges. From the study, it indicates that 69 percent found it difficult to study remotely, while 7 percent said it was impossible to study online (World Economic Forum, 2020). The less digitally prepared youth, those with underneath university education and those living away from urban communities were likely to confront troubles in concentrating on online learning. Those without internet accessibility would be badly affected. In ASEAN, only Singapore, Brunei and Malaysia have over 80 percent internet coverage. Countries like Indonesia, Thailand and Cambodia have less than 60 percent of the population having access to the internet, and only 40 percent in Myanmar and Vietnam have access to the internet (Yarrow, 2020).

Developing countries still lag behind in online learning. Some of the countries still use outdated information and communication technologies. Bhuasiri (2012) indicated some obstacles to online learning in developing countries, namely investments in technology such as hardware, software licenses, learning material development, equipment maintenance, and training. Taking example of Indonesia, Michael (2013) stated educators in Indonesia are using video recording in delivering their contents of learning. It is a more cost-effective way rather than having to use laptop. Human factor also contributes to this issue. Yarrow (2020) posited that in a survey of 1,045 students conducted by the Indonesia University of Education, 48 percent of students appeared to need more time to get used to internet-based learning, despite the availability of teaching applications.

The commitment of Information Communication and Technology (ICTs) to general access affects influence as far as equity in education, the transmission of quality learning and teaching, teachers' professional growth and more effective education management, administration and organization. According to Utakrit (2016) the ASEAN member countries should cooperate and develop education to have an equal standard in technology because the communication between the countries needs to have the Information Technology (IT) equipment to support. The report about youth and online learning was not all dreadful. Online learning has numerous positive attributes also. A report by Broom (2020) stated that significant growth in the use of online learning was ASEAN's youth's strong aspiration for lifelong learning and growth mindset. This signifies positive remarks on online learning. According to Nam-Nguyen et. Al., (2021), all of the students agreed that the following attitudes were gained 
because of the participation in the online activities: becoming environmentally responsible, becoming critical in assessing local environmental policies, valuing the importance of time management, and developing creativity. Also, when refined proficiently and effectively, online classes in Vietnam will be an awesome instrument to resolve issues with respect to online learning. As in Singapore, effective learning online experience for the students' culture at the national, ethnic and cyber levels could have influenced what they considered useful, enjoyable and effective. (Fang, 2007).

The implementation of online learning among youth students in developed and developing countries differ particularly in the technology adoption, yet no matter what it takes, youth students in the world need to adapt to the new learning norm due to pandemic Covid 19. Noting that, past researchers putting effort to cover on empirical study, efforts to systematically review these studies are still lacking. Thus, this article aims to fill the gap in understanding and identifying factors affecting youth online learning in ASEAN countries.

\section{Methodology}

Guided by the PRISMA Statement (Preferred Reporting Items for Systematic reviews and Meta-Analyses) review method, a systematic review based on two main database i.e. Scopus and Web of Science were conducted. Scopus and Web of Science are among the largest abstract and citation databases of peer-reviewed literature which comprise diverse subject areas namely social sciences, computer science, psychology, arts and humanities and decision sciences. The systematic review process involved four (4) main processes, namely identification, screening, eligibility and data analysis. The systematic review process for this paper is as follows:

\section{Identification}

The first phase of systematic review process is identification, thereby four techniques were used to search reading sources from the Scopus database, namely field code function, phrase searching and truncation. The keyword used in the search string is youth online learning. The summary of search string used is depicted in Table 1 below. 
Table 1: The Search String Used for The Systematic Review Process

\begin{tabular}{|c|c|}
\hline Database & Keywords used \\
\hline Scopus & $\begin{array}{l}\text { Field code function: } \\
\text { TITLE-ABS-KEY Youth online learn = } 133 \\
\text { articles } \\
\text { Phrase searching: } \\
\text { Youth AND "online learning" = } 64 \text { articles } \\
\text { Truncation: } \\
\text { Youth online learn = } 795 \text { articles Youth } \\
\text { online learn = } 775 \text { articles Youth online learn } \\
=11 \text { articles Youth online learn = } 133 \text { articles } \\
\text { Boolean } \\
\text { Youth AND online AND learn AND NOT } \\
\text { children = } 105 \text { articles } \\
\text { Youth AND online AND learn AND NOT }\end{array}$ \\
\hline Web of Science & $\begin{array}{l}\text { Eield code function: } \\
\text { TITLE-ABS-KEY Youth online learn = } 613 \\
\text { articles } \\
\text { Phrase searching: } \\
\text { Youth AND "online learning" = } 613 \text { articles } \\
\text { Truncation: } \\
\text { Youth online learn = } 660 \text { articles Youth } \\
\text { online learn = } 632 \text { articles Youth online learn } \\
\text { =6 articles Youth online learn = } 613 \text { articles } \\
\text { Boolean } \\
\text { Youth AND online AND learn NOT children } \\
=471 \text { articles }\end{array}$ \\
\hline
\end{tabular}

\section{Screening}

Several inclusion and exclusion criteria have been determined. For the purpose of this paper, five main criteria were outlined, which comprised literature type, language, timeline, countries and territories as well as subject area.

In terms of literature type, only research articles with empirical data from journal were included in this paper. Thus, other types of articles namely systematic review, meta-analysis, book series, book, note, undefined, chapter-in-book, conference proceeding, trade publication and editorial were excluded.

With regards to timeline and language, in an attempt to ease understanding of interpreting contents of the past articles, only articles of English language were selected to be reviewed for this paper. As for the timeline, it has been set for selection in terms of papers to be reviewed between the years 1992 and 2021.

With regards to countries and territories, only papers of the following countries namely Myanmar, Thailand, Cambodia, Malaysia, Singapore, Indonesia, Brunei Darussalam, Vietnam, Laos and Philippines were selected to be reviewed, as those papers have been research conducted in ASEAN countries. The subject areas covered for the paper selected were 
diverse, such as social sciences, computer science, psychology, arts and humanities and decision sciences (refer Table 2 below).

Table 2: Inclusion and Exclusion Criteria

\begin{tabular}{|l|l|l|}
\hline \multicolumn{1}{|c|}{ Criterion } & Eligibility & Exclusion \\
\hline Literature type & Journal (research article) & $\begin{array}{l}\text { Journals (systematic review, } \\
\text { review, meta-analysis, meta } \\
\text { synthesis), book series, book, } \\
\text { note, undefined, chapter-in- } \\
\text { book, }\end{array}$ \\
\hline Language & $\begin{array}{l}\text { enferenc } \\
\text { proceeding, trade publication } \\
\text { and editorial }\end{array}$ \\
\hline Timeline & Non-English \\
\hline Countries and territories & Asian countries & Before year 1992 \\
\hline
\end{tabular}

\section{Eligibility}

In this phase, a total of 576 remaining articles resulted from the identification process were examined thoroughly to ensure their fit of the criteria determined. The examination was conducted manually by the researchers. The completion of eligibility phase resulted in 11 articles that were closely related with research in hand. Therefore, the 11 articles would be further analyzed through qualitative synthesis review process.

\section{Data Analysis}

The remaining eleven (11) articles were assessed and analyzed. The analysis was focused on specific studies related to the formulated questions. The data were extracted by reading through the abstracts first, then the full articles (in-depth); to identify main issues and appropriate themes. Then the other remaining articles were also assessed and analyzed, with great emphasis on responses related to the formulated questions. The data were extracted by reading through the abstracts first, and then the full articles (in-depth), in order to identify appropriate themes. Qualitative analysis was performed using content analysis to identify those themes related to youth online learning in ASEAN countries.

\section{Results}

Based on the eleven (11) articles assessed, analysed and reviewed, three main themes were developed related to youth online learning. The three main themes are preferences of online learning tools among ASEAN youth, youth opinion on online learning and youth motivation on online learning.

A total of five (5) studies focused on qualitative approach (Rahiem, 2021; Cleofas, 2020; Jamaludin \& Hung, 2017; Yusof, 2008; Jamaluddin, 2012), four (4) studies focused on mixed mode approach (combination of qualitative and quantitative studies) (Zakaria, et.al., 2014; Mueangpud \& Khlaisang, 2019; Lamb \& Arisandy, 2020; Said, et.al., 2018), while the remaining two (2) studies focused on quantitative approach (Hamat, et al., 2012; Al-Dheleai \& Tasir, 2017) (refer Table 3 below). 
As depicted in Table 3 below, a total of three (3) studies focused on youth online learning in Indonesia (Lamb \& Arisandy, 2020; Rahiem, 2021; Said, et.al., 2018) and three (3) studies focused on youth online learning in Malaysia (Hamat, et.al., 2012, Yusoff, 2008; Al-Dheleai \& Tasir, 2017) while two (2) studies focused on youth online learning in Singapore (Jamaludin \& Hung, 2017; Jamaluddin, 2012). On the other hand, one study focused on youth online learning in Brunei (Zakaria, et.al. 2014), Thailand (Mueangpud, 2019) and Philippines (Cleofas, 2020) respectively.

Table 3: Studies Covered on Youth Online Learning in ASEAN Countries

\begin{tabular}{|l|l|l|}
\hline Sources (Author \& year) & Country & $\begin{array}{l}\text { Qualitative, } \\
\text { Quantitative or } \\
\text { Mixed Mode }\end{array}$ \\
\hline 1. Zakaria, Tajudeen, Nawi \& Mahalle, 2014 & Brunei & Mixed method \\
\hline 2. Mueangpud, 2019 & Thailand & Mixed method \\
\hline 3. Rahiem, 2021 & Indonesia & Qualitative \\
\hline 4. Lamb \& Arisandy, 2020 & Indonesia & Mixed method \\
\hline 5. Cleofas, 2020 & Philippines & Qualitative \\
\hline 6. Hamat, Embi, \& Hassan, 2012 & Malaysia & Quantitative \\
\hline 7. Jamaludin \& Hung, 2017 & Singapore & Qualitative \\
\hline 8. Yusoff, 2008 & Malaysia & Qualitative \\
\hline 9. Jamaludin, Kim \& Hung, 2012 & Singapore & Qualitative \\
\hline 10. Said, Kurniawan \& Anton, 2018 & Indonesia & Mixed method \\
\hline 11. Al-Dheleai \& Tasir, 2017 & Malaysia & Quantitative \\
\hline
\end{tabular}

Based on the synthesis of the qualitative review above, the following will be discussed on three main themes, namely online learning tools among ASEAN youth, youth opinion on online learning and youth motivation on online learning.

\section{Preferences of Online Learning Tools Among ASEAN Youth}

The first theme extracted based on paper review is preferences of online learning tools among ASEAN youth. A total of eight (8) studies covering on this theme, namely (Al-Dheleai \& Tasir, 2017, Zakaria, et.al., 2014, Hamat, et.al., 2012, Jamaludin \& Hung, 2017, Jamaludin, et.al., 2012, Lamb \& Arisandy, 2020, Mueangpud, 2019 as well as Yusoff, 2008).

On the same note, it is further discovered that Malaysian youth students use social networking sites (SNS) for informal learning. However, only half of them use social networking sites (SNS) to interact with their lecturers, using it more for socializing rather than learning (Hamat, et.al., 2012). On the same notion, the interactive nature of social media such as Facebook is preferred among Malaysian youth students as they can complete their academic task while interacting with their peers using Facebook, thus this has increased their academic performance (Al-Dheleai \& Tasir, 2017). In learning creative writing, Malaysian youth students prefer to use e-portfolio in their creative writing subjects, particularly for poetry and short story writing. In this manner they can creatively store and upload their work and receive instant feedbacks from viewers (Yusof, 2008).

In Singapore, the use of entertainment oriented for activity does not confine for language subject only, but also for science, technology, engineering, and mathematics (STEM) based 
subjects. For example, Singaporean youth learners prefer the use of multiplayer online roleplaying game (MMORPG) and World of Warcraft (WoW) for problem-solving skill acquisition in STEM based subjects (Jamaludin \& Hung, 2017). Jamaludin, Kim and Hung (2012) further added that the use of WoW game are preferred by Singaporean youth students since the game makes them feel important due to their ability to assist other players in problem solving and become a mentor to new game players.

The preferences of online learning tools seems to differ across ASEAN country in STEM based subjects. For example, Thai youth prefer to learn financial management using social sharing and consultation with financial experts (Mueangpud, 2019). The different of learning tools preferences may be due to the different development growth between these two countries, where Singapore is a developed country as compared to Thailand which is still a developing country.

In contrast, Indonesian youth students prefer entertainment oriented (heard/read in songs, digital game, videos and websites) and self-instruction-oriented activity (using Google translate and language website when needed), as compared to social activity in learning English language subject (Lamb \& Arisandy, 2020).

On the other hand, although Brunei youth learners have similar preferences with Indonesian youth, they also prefer self-instruction activity. However, Brunei youth learners prefer to take up challenges; adding on to the fact that they prefer to learn and understand Al- Quran through Arabic language, without making use of language translation tool (Zakaria, et.al., 2014).

\section{Youth Opinion on Online Learning}

Based on the analyses, the second theme extracted from the review is youth opinion on online learning. Only six (6) studies discussed on youth opinion on online learning namely Hamat, et al (2012); Cleofas (2020); Jamaludin, Kim \& Hung (2012); Al-Dheleai and Tasir (2017); Said, et.al (2018) as well as Zakaria, et.al. (2014).

Both authors, namely Hamat, et.al (2012) as well as Cleofas (2020) agreed that online learning is insufficient in improving student academic performance and competency, and lacking of interaction between teachers and students. Online learning itself does not successfully improve Malaysian student academic performance (Hamat, et.al., 2012) whilst Brunei youth students feel lack of interaction between teachers and student in online learning, especially in regards to learning AL-Quran (Zakaria, et.al., 2014). However, it makes Filipino (Cleofas, 2020) and Indonesian youth students (Said, et.al., 2018) become more competent which is mainly due to the speed of information and learning materials delivery (Said, et.al., 2018).

The interactive means of online learning such as game space of World of Warcraft (WoW) increase Singaporean youth students in their social equality, togetherness and solidarity (Jamaludin, Kim \& Hung, 2012). In line with that, the use of social media such as Facebook is also believed to provide good interaction, ability to initiate discussion and control learning environment among Malaysian youth students, thus they are able to boost their academic performance (Al-Dheleai \& Tasir, 2017). 


\section{Youth Motivation for Online Learning}

The third theme extracted from the review is youth motivation on online learning. Only three (3) studies discussed this theme, namely Rahiem (2021); Al-Dheleai and Tasir (2017) as well as Hamat, et.al (2012).

The motivation of Indonesian youth students for remote/mobile learning has been enhanced by personal, social and environmental factors. Under personal factors, several sub- factors have been outlined namely challenge, curiosity, self-determination, satisfaction and religious commitment. As for the second factor that is social factors, the sub-factors associated with it are relationships, inspiration, and well-being of self and others. Finally, the third factor for youth motivation is environmental, that the sub-factors comprised facilities and conditioning (Rahiem, 2021).

Meanwhile, the motivation of Malaysian youth students for online learning using Facebook highly depends on the support of their fellow students to assist in their learning of courses and to motivate them to continue their studies (Al-Dheleai \& Tasir (2017). On the contrary, Hamat, et.al., (2012) found that Malaysian youth students are only motivated to gauge informal learning using social networking sites, but are not able to comprehend formal learning using social networking sites.

\section{Discussion}

The three main themes elaborated above are preferences of online learning tools, youth opinion on online learning and youth motivation on online learning in the ASEAN perspective. Hence, this section will expand the above results, looking deeper into these three main themes.

\section{Preferences of Online Learning Tools Among ASEAN Youth}

Nowadays, educating the youth is confronted by various challenges which demand much of time, effort and resources. They demand the educators to replace the traditional instructions with the new technologies (Belal, 2011). From the view point of Mohr and Mohr (2017), their exposure to cable TV, smart phones, video games, computer software and internet had much to say about their learning preferences which lead them to have unique characteristics and learning preferences. The youth now belong to an exclusive generation that is optimistic, collaborative, team-oriented, and are very reliant on technology (Chaudhuri, 2018) and they also prefer visuals and graphics than texts (Chaudhuri, 2018; Mohr \& Mohr, 2017)

On the other hand, Ortega-Dela Cruz (2020) finds that digital games help students learn subject matter in context, as part of an interactive system. Therefore, gamification takes an element of education and replaces it with a game-based element. Meanwhile, Camp et al., (2012) added that having students play games has increased participation, interaction, interest and learning. For instance, a serious game environment can promote student learning and motivation (Erhel \& Jamet, 2013; Wouters et al., 2013). Another factor for the acceptance of digital game-based learning, according to EDUCAUSE Review, is that today's students are a part of a digital generation that has become disengaged with traditional instruction (Foreman, 2004). 
In online learning, there are several possible reasons being raised by young students in the ASEAN region. One of these is the use of foreign languages in online learning. Using the online learning system also affects the use of a curriculum that is relevant or in accordance with the current situation. The completeness of online learning among millennials is also influenced by online networks in several countries that are connected to one another. Online learning will also determine how proficient this younger generation is when using ideas in running online learning media. Usually, in general, motivation in learning through online preferences is largely determined by motivation or strong ideas in a person to give his best action in the learning process. Motivation can be in the form of extrinsic motivation, which is related to factors outside the classroom, which intrinsic motivation is related to what happens in the classroom (Ahmed, 2015). Similar research has been conducted by Pillai (2018), that has shown the results of research reflecting on the role of socio-culture in the learning process, which subsequently can determine the success of online learning methods. The ecosystem in online learning can stimulate young people from several countries to carry out entrepreneurial activities, namely how the learning process can support and stimulate economic entities in significant ways.

Online learning practices across countries also depends on the capabilities of its human resources (particularly its young generation). Technological progress is a determinant in this field that personal and interpersonal skills can support online learning. Thus, it is very important that the highest standards in online learning greatly determine the objectives, components, as well as knowledge and education in a country (particularly within the scope of ASEAN countries), online learning also tends to give users choices in using their learning styles (Magulod Jr, 2019).

In Vietnam, although there is a need to increase the productivity of online learning from young learners, it turns out that online learning activities have an effect on the psychology and mentality of students in using learning media. This is due to several reasons, namely the lack of instruments or other obstacles in their learning process (Minh-Uyen \& Im, 2020). Among the many benefits of online learning in several countries in ASEAN, the relationship or connectivity between policy makers and youth in carrying out the online education process is very important. It will automatically unite a learner with a system that has been built based on needs, hence this increases public participation in the learning balance of young people in ASEAN (Amin et.al., 2017).

\section{ASEAN Youth Opinion on Online Learning}

By involving young people in online learning in the ASEAN region, this will automatically become a process of change, in which young people will usually generate new ideas or ideas, bring out a wealth of new creativity and new knowledge as well. Having great awareness about the potential for the spread of new knowledge can strengthen efforts to promote the potential of every youth in the ASEAN region (Ahrari, et.al., 2019).

In the last few decades, knowledge gained through online learning has slowly begun to be introduced in various ways; through the implementation of policies and business activities among countries. Therefore, the existence of online activities has changed all forms of manual activities towards virtual ones (Hoang, et.al., 2020). This is in line with research conducted by Schack \& Foundation (2015) which resulted in research that the effectiveness 
of e-learning activities has increased in recent years. This is mainly due to the increased possibilities for the use of Information Technology (IT) in learning and the increased attention towards regulation of youth organizations which are very relevant in this current era. Based on the results of this study, e-learning has been very effective in use several times, namely the use of e-learning in politics, e-learning in organizations, and e-learning in the field of business. In addition, it has been observed that young people continue to strive to be creative, particularly to motivate them to generate more ideas (Sopin, 2015).

As Malaysia strives to move towards Education 4.0, online learning has become prudent in order to make it sensible. Education 4.0 integrates innovation in learning and being selfdirected in learning. Malaysian universities have adopted the use of technology in teaching and learning since the 1990s (Maria et al., 2018). According to Serena and Catherine (2020), online learning platforms enable students to convey messages with more autonomy and convenience. Malaysian youth students are free to interact with educators and members in the cycle whenever and wherever they feel easy to connect. It is also developing the confidence level for introvert students who will use online learning facilities to engage with their educators and members in the same course. In online learning, the learner must dynamically process and

make logic of available information. A study conducted by Hussin et al., (2009) at the International Islamic University Malaysia, it was found that in online learning the students were satisfied with the materials in the module, as they were well organized. Therefore, they were easy to find, the text was easy to read and understand, the graphics and video complemented the learning materials and contained a lot of information about the topic covered.

Singapore national culture has influenced how Singaporean's students interact online: they were more collectivist compared to their US counterparts; they were less willing to challenge the majority position; and the majority influence remained unchanged when computermediated communication (CMC) replaced verbal and visual communication (Tan et. al., 1998). Supported by Linda (2007), the seemingly passive learners online can be in actual fact, are active learners. Students' preferences for what they wanted to learn, how and with whom, influenced the way they reacted to the materials, tasks and activities. The other member of ASEAN countries such as Indonesia also benefits from online learning approach. In Indonesia, the development of e-learning or online education is now in a quite encouraging stage. At present there are quite a number of universities that make learning innovationsusing information and communication technology, including Universitas Terbuka (UT), Universitas Indonesia (UI), Institut Teknologi Sepuluh Nopembe (ITS), Universitas Gadjah Mada (UGM), Institut Teknologi Bandung (ITB), Institut Pertanian Bogor (IPB), Universitas Teknokrat Indonesia and many others (Ayu, 2020). Students feel encouraged when they have been provided sufficient contents in online learning. Additionally, according to Ayu (2020) the students were enthusiastic during learning because teaching materials or materials were easily accessed online and were relevant for use where the materials uploaded allow independent learning.

The youth are the key drivers of internet use in the Philippines, such that while half of those aged 18 to 24 are internet users, a small $2 \%$ of those aged 55 and above also use the internet 
(Labucay, 2011). In a study conducted by Katrina (2018), students were more confident in expressing their opinion through the discussion board more than classroom discussion. It is equally critical that while students communicated well in the comfort of working at home, it releases them from the pressing factor of time and direct criticism. They have their own space to learn online. Similar situation happens in Thailand. Youth believe that learners who have participated in interactive activities with friends or classmates would be able to improve their learning ability more than the lone learner (Charuwan, et.al. (2015). Some of the students need to learn new skills in online learning. This is supported by Thosporn (2015) that new technology tips and tricks need to be regularly updated.

In Brunei, student satisfaction is also linked to residence location, previous online learning experience as well as use of online learning resources by a friend or family. This is because Bruneians have more access to technology and are used to online teaching modules (Qazi et al., 2020). Whereas for Myanmar youth, students are able to control their own learning at their own preferred time. Thus, the benefit of online learning for Myanmar students is that they are not confined to the pace of the slowest learners in the classroom (Robert, 2002).

\section{ASEAN Youth Motivation on Online Learning}

Motivation in learning through online preferences is largely determined by motivation or strong ideas and ideas in a person to give his best action in the learning process. Motivation can be in the form of extrinsic motivation, which is related to factors outside the classroom, and intrinsic motivation, which is related to what happens in the classroom (Ahmed, 2015).

Motivation had been described by Paris and Turner (1994) as the engine of learning. Research shows that motivated learners are more likely to undertake challenging activities, to be actively engaged, to experience joy and to adopt a deep approach to learning and exhibit enhanced performance, persistence and creativity (Ryan and Deci, 2000). For the relationship between motivation and online learning satisfaction, it is reported that motivation is an essential prerequisite for learners' learning in web-based environments (Hoskins and van Hooff, (2005); Song, et.al., 2004).

Ortega-Dela Cruz (2020) affirmed how unique the generation of present day learners; they are a multi-modal generation and therefore, demand pedagogical practices that engage multiple channels of learning and on ways of assessing the learning outcomes. Thus, this way of building the pedagogical practices on the students' intuitive skills in technology will make the learning experiences more meaningful. Therefore, the educators need to embrace the power of technology to make learning relevant for all students in higher education and need to adopt these pedagogical practices that empower students to take more responsibility for their own learning. This will also help educators to better understand their students. Educators need to

acquire online-driven competencies in planning, implementing and assessing the performance of their students. These online-driven competencies can assist them in implementing the courses through electronic delivery effectively (Toquero, 2020).

Bollag and Overland (2001) advised that for an online learning environment to be successful, it must be suited to the specific cultural needs of the group. In Cambodia, Crews \& Parker (2017) found that the students had no prior exposure to online learning, therefore it was also 
important to use appropriate methods to introduce them to new terminology and how to use the online tools. The research also confirmed that the online learning research indicates that successful online learning requires well-developed self-regulated learning skills. Additionally, Abdon, et.al., (2007) contend that the chances of success for Cambodians are significantly increased when content is appropriate and learning is affordable.

Additionally, according to Ngampornchai \& Adams (2016), the Thai learning environment that fosters rote learning contrasts sharply with the online education approach that relies on the learners' self-motivation and self-regulation. Youth become motivated to do online learning due to the fact that they can easily arrange their convenient time to access materials of the courses in between their hectic schedule.

Bakar et al (2010) conducted a study on 1484 students at Universiti Putra Malaysia (UPM) to identify the relationships between achievement motivation, attitude and student academic performance. The authors found significant relationship between achievement motivation and student's attitude for online learning, and also found positive correlations between academic achievement and student's attitude. In other findings, Ab Jalil, et.al (2008) pointed out that assisted performance in the online exchanges can offer insights into the learning that can take place in online discussion. It also offers one way of recognizing meaningful online interaction. Thus, this increases the motivation level of youth to study using online learning.

\section{Conclusion and Recommendations}

This systematic review has highlighted the youth online learning in ASEAN countries. In the past nine years, it has been discovered that several youth online learning articles have been published throughout the world. A total of eleven articles discovered with three main themes relating to youth online learning namely online learning tools among ASEAN youth, youth opinion on online learning and youth motivation on online learning. Several online learning tools are being preferred to be used by youth students in ASEAN countries namely, social networking sites, entertainment video and websites, and multiplayer online roleplaying game. Additionally, in ASEAN countries, youth believed that online learning solely is insufficient in improving their academic performance and make them become more competent. It is further highlighted that youth students can be motivated for online learning, using several factors namely personal, social and environmental factors.

This research only covered on youth online learning in ASEAN countries. Thus, behaviour of online learning across different age groups, education levels, countries and culture may differ and warrant further research. Noting that there are many loopholes in this research that remain uncovered, it would be interesting for future qualitative researchers to conduct systematic or umbrella review, or even conduct personal interview or focus group with teachers, instructors and facilitators as well, which may provide different insights and perspectives.

\section{Acknowledgements}

The researchers would like to acknowledge the Faculty of Business and Management, Universiti Teknologi MARA Campus Selangor, Puncak Alam, for the fund received through Grant Project title: The Impact of Knowledge and Presence (Cognitive, Teaching and Social 
Presence) of Unified Communication Towards Tertiary Student Satisfaction in Online Learning; Project File No: 600-IRMI-TNCPI 5/3/DDF (FPP) (19/20). Utmost thanks go to the faculty and members of the team for the excellent support to internalise the objectives of this study

\section{References}

Ab Jalil, H., McFarlane, A., Ismail, I. A., \& Rahman, F. (2008). Assisted Performance A Pragmatic Conception of Online Learning. Online Submission, 1(2), 57-75.

Abdon, B. R., Ninomiya, S., \& Raab, R. T. (2007). E-learning in higher education makes its debut in Cambodia: Implications of the Provincial Business Education Project. The International Review of Research in Open and Distributed Learning, 8(1).

Ahmed, S. (2015). Attitudes towards English Language Learning among EFL Learners at UMSKAL. Journal of Education and Practice, 6(18), 6-17.

Ahrari, S., Krauss, S. E., Ariffin, Z., \& Meng, L. K. (2019). “Making a Difference ... on My Own Terms": Motivational Factors of Youth Involvement in Social Entrepreneurship in Malaysia. Societal Entrepreneurship and Competitiveness, 227-246. https://doi.org/10.1108/978-1-83867-471-720191015.

Al-Dheleai, Y. M., \& Tasir, Z. (2017). Using Facebook for the Purpose of Students' Interaction and its Correlation with Students' Academic Performance. The Turkish Online Journal of Educational Technology, 16(4), 170-178.

Amin, N. A. N., Wuen, C. H., \& Ismail, A. (2017). Leadership style desired by youth in Asia. Journal of Management Development.

Ayu, M. (2020). Online learning: Leading e-learning at higher education. The Journal of English Literacy and Education, 7(1), 47-54.

Babson Survey Research Group. (2014). Babson Study: Over 7.1 million higher ed students learning online. Babson College, 2014. Retrieved from http://www.babson.edu/newsevents/babson-news/Pages/140115-babson-survey-study-of-online-learning.aspx.

Bakar, K. A., Tarmizi, R. A., Mahyuddin, R., Elias, H., Luan, W. S., \& Ayub, A. F. M. (2010). Relationships between university students' achievement motivation, attitude and academic performance in Malaysia. Procedia-Social and Behavioral Sciences, 2(2), 4906-4910.

Belal, A. R. (2011). Students Perceptions of Computer Assisted Learning: An Empirical Study. International Journal of Management in Education, 5(1), 63 - 78. doi:10.1504/IJMIE.2011.037755.

Bhuasiri, W., Xaymoungkhoun, O., Zo, H., Rho, J.J. \& Ciganek, A. P. (2012). Critical Success Factors for E-learning in Developing Countries: A Comparative Analysis between ICT Experts and Faculty. Computers and Education, 58(1), 843-855.

Bollag, B., \& Overland, M. A. (2001). Developing countries turn to distance education. Chronicle of Higher Education, 47, 40, A29-22.

Broom, D. (2020). Young people in ASEAN have emerged from lockdowns more resilient and digitally switched on. Here's how. World Economic Forum.

Camp, K. M., Avery, S., \& Lirely, R. (2012). Cooperative-Experiential Learning: Using StudentDeveloped Games to Increase Knowledge Retention. Marketing Faculty Publications and Presentations. Paper 1.

Cao, W., Fang, Z., Hou, G., Han, M., Xu, X., Dong, J., \& Zheng, J. (2020). The psychological impact of the COVID-19 epidemic on college students in China. Psychiatry Research, 287, 112934. 
Chaudhuri, J. D. (2018). Teaching the Generation Y Anatomy Student. EC Clinical and Experimental Anatomy, 1, 62-70. https://www.ecronicon.com/eccea/pdf/ECCEA-0100009.pdfC.

Chou, C., \& Hsiao, M. C. (2000). Internet addiction, usage, gratification, and pleasure experience: the Taiwan college students' case. Computers \& Education, 35(1), 65-80.

Cleofas, J. V. (2020). Life Interruptions, Learnings and Hopes among Filipino College Students during COVID-19 Pandemic. Journal of Loss \& Trauma, 1-9.

Crews, J., \& Parker, J. (2017). The Cambodian experience: Exploring university students' perspectives for online learning. Issues in Educational Research, 27(4), 697-719.

Curtain, R. (2002). Online delivery in the vocational education and training sector. Retrieved from http://www.flexiblelearning.net.au.

Department, S. R. (2020). Assessment of current education and skills level among youths in Vietnam 2019.

Dewantoro, A., \& Rachmawati, I. (2020). Analysis of evaluation and exploratory studies on student's resilience of online learning during pandemic of covid-19. KONSELI:Jurnal Bimbingan dan Konseling (E-Journal), 7(2), 155-162.

Didin, F. S., Mardiono, I., \& Yanuarso, H. D. (2020). Analisis Beban Kerja Mental Mahasiswa saat Perkuliahan Online Synchronous dan Asynchronous Menggunakan Metode Rating Scale Mental Effort. OPSI, 13(1), 49-55

Erhel, S., \& Jamet, E. (2013). Digital Game-Based Learning: Impact of Instructions and Feedback on Motivation and Learning Effectiveness. Computers \& Education, 67, 156167. https://doi.org/10.1016/j.compedu.2013.02.019

Fang, L. (2007). Perceiving the Useful, Enjoyable and Effective: A case study of the e-learning experience of tertiary students in Singapore. Educational Media International, 44(3), 237-253.

Fang, L. M. L. (2007). Through Singaporean eyes: How young adults learnt online. 2007 Annual Proceedings-Anaheim: Volume, 86.

Foreman, J. (2004). Game-Based Learning: How to Delight and Instruct in the 21st Century. EDUCAUSE Review, 39(5). Retrieved 2 September 2020 from https://www.learntechlib.org/p/98263/.

Hamat, A., Embi, M. A., \& Hassan, H. A. (2012). The Use of Social Networking Sites among Malaysian University Students. International Education Studies, 5(3).

Herman, P. C. (2020). Online learning is not the future. The Chronicle of Higher Education.

Hoang, G., Le, T. T. T., Tran, A. K. T., \& Du, T. (2020). Entrepreneurship education and entrepreneurial intentions of university students in Vietnam: the mediating roles of selfefficacy and learning orientation. Education and Training, 63(1), 115-133. https://doi.org/10.1108/ET-05-2020-0142.

Hoskins, S. L., \& van Hooff, J. C. (2005). Motivation and ability: Which students use online learning and what influence does it have on their achievement? British Journal of Educational Technology, 36, 177192.

Hussin, H., Bunyarit, F., \& Hussein, R. (2009). Instructional design and e-learning: Examining learners' perspective in Malaysian institutions of higher learning. Campus-Wide Information Systems.

Islam, M. A., Barna, S. D., Raihan, H., Khan, M. N. A., \& Hossain, M. T. (2020). Depression and anxiety among university students during the COVID-19 pandemic in Bangladesh: A webbased cross-sectional survey. PLoS One, 15(8), e0238162. 
Jalli, N. (2020), "Commentary: E-learning sees no smooth sailing in Malaysia and Indonesia", available at: https://www.channelnewsasia.com/news/commentary/coronaviruscovid- 19-malaysiaindonesia-school-e-learning-online-12616944 (accessed 25 may 2020).

Jamaludin, A., \& Hung, D. (2017). Problem-solving for STEM learning: navigating games as narrativized problem spaces for 21st century competencies. Research and Practice in Technology Enhanced Learning, 12(1), 1-14.

Jamaludin, A., Kim, M. S., \& Hung, W. L. D. (2012). Unpacking self and socio dialectics within learners' interactive play. Computers \& Education, 59, 1009-1020.

Kemp, S. (2015). Digital, social, and mobile in APAC 2015. Retrieved from http://wearesocial.sg/blog/2015/03/digital-social-mobile-in-apac-in-2015

Kritpracha, C., Kaosaiyaporn, O., \& Atisabda, W. (2015). Expectation of educators and students towards a distance learning model in Southernmost Provinces of Thailand. Procedia-Social and Behavioral Sciences, 174, 2349-2354.

Labucay, I. D. (2011). Internet use in the Philippines. In Annual Conference of the World Association for Public Opinion, 21-21.

Lamb, M., \& Arisandy, F. E. (2020). The Impact of Online Learning Use of English Language on Motivation to Learn. Computer Assisted Language Learning, 33(1-2), 85-108.

Lederman, D. (2018). Who is studying online (and Where): Inside Higher Education. Magulod Jr, G. C. (2019). Learning Styles, Study Habits and Academic Performance of Filipino University Students in Applied Science Courses: Implications for Instruction. Journal of technology and science education, 9(2), 184-198. Retrieved from http://www.jotse.org/index.php/jotse/article/view/504.

Mahaisavariya, B. (2020), "Guideline for educational and other activities in Mahidol university during the lockdown lift of the COVID-19 monitoring measures", available at: https://mahidol.ac.th/temp/2020/08/12-08-63-ENG.pdf (accessed 14 October 2020).

Maria, M., Shahbodin, F., \& Pee, N. C. (2018). Malaysian Higher Education System Towards Industry 4.0 - Current Trends Overview. 2016, 020081.doi:10.1063/1.5055483.

Mason, R., \& Rennie, F. (2006). E-learning: The key concepts. New York, NY: Routledge. Michael, T. (2005). Knowledge Maps: ICTs in Education. Washington, DC: infoDev / World Bank.

Michael, T. (2013). Using video to improve teaching-and support teachers. World Bank Group.

Minh-Uyen, V. T., \& Im, S. (2020). Psychometric examination of the Connor-Davidson resilience scale (CD-RISC-10) among Vietnamese students. Journal of Applied Research in Higher Education, 13(1), 325-341. https://doi.org/10.1108/JARHE-05- 2019-0116.

Mohr, K. A., \& Mohr, E. S. (2017). Understanding Generation Z Students to Promote a Contemporary Learning Environment. Journal on Empowering Teaching Excellence, 1(1), 9. https://doi.org/10.15142/T3M05T.

Morahan-Martin, J. S. P. (2013). Incidents and correlates of pathological internet use among college students," Computers in Human Behavior, 16, 13-29.

Mueangpud, A., Khlaisang, J., \& Koraneekij, P. (2019). Mobile Learning Application Design to Promote Youth Financial Management Competency in Thailand. International Journal of Interactive Mobile Technologies, 13(12), 19-38.

Nam-Nguyen, V., Truong, T. T., Ly, D. T., \& Dagamac, N. H. A. (2021). Perceptions of Environmental Science and Management Students on Synchronous Online Teaching of 
Environmental Policies: Learning Experience from Southeast Asian Cohort. Pedagogical Research, 6(1).

Ngampornchai, A., \& Adams, J. (2016). Students' acceptance and readiness for E-learning in Northeastern Thailand. International Journal of Educational Technology in Higher Education, 13(1), 1-13.

N. V. F. (2010). New Forms of Human Resources Development: E-learning in Education. Buletinul - Universitatii petrol-Gaze din Ploiesti, 62(1A), 249-257.

Cruz, O-D. R. (2020). Pedagogical practice preferences among generational groups of learners: Towards effective twenty-first century higher education. Journal of University Teaching \& Learning Practice, 17(5), 6.

Paris, S. G., \& Turner, J. C. (1994). Situated motivation. In P. R. Pintrich, D. R. Brown \& C.E. Weinstein (Eds.), Student motivation, cognition, and learning: Essays in honor of Wilbert J. McKeachie (pp. 213-237). Hillsdale, NJ: Lawrence Erlbaum.

Qazi, A., Naseer, K., Qazi, J., AlSalman, H., Naseem, U., Yang, S., ... \& Gumaei, A. (2020). Conventional to online education during COVID-19 pandemic: Do develop and underdeveloped nations cope alike. Children and Youth Services Review, 119, 105582.

Rahiem, M. D. H. (2021). Remaining motivated despite the limitations: University students' learning propensity during the COVID-19 pandemic. Children and Youth Services Review, 120, 1-14.

Ryan, R. M., \& Deci, E. L. (2000). Self-determination theory and the facilitation of intrinsic motivation, social development, and well-being. American Psychologist, 55(1), 68-78. doi: 10.1037/0003-066X.55.1.68.

Said, K., Kurniawan, A., \& Anton, O. (2018). Development of Media-Based Learning Using Android Mobile Learning. Journal of Theoretical and Applied Information Technology, 96(3), 668-676.

Sangsawang, T. (2015). Instructional design framework for educational media. Procedia-Social and Behavioral Sciences, 176, 65-80.

Schack, S., \& Foundation, K. (2015). The Effectiveness of E-Learning: An Explorative and Integrative Review of the Definitions, Methodologies and Factors that Promote eLearning Effectiveness ResearchLAB: IT and Learning Design, Dept. of Learning and Philosophy, Aalborg. The Electronic Journal of E-Learning, 13(4), 278-290.

Sia, J. K. M., \& Adamu, A. A. (2020). Facing the unknown: pandemic and higher education in Malaysia. Asian Education and Development Studies.

Singh, V., \& Thurman, A. (2019). How many ways can we define online learning? A systematic literature review of definitions of online learning (1988-2018). American Journal of Distance Education, 33(4), 289-306.

Song, L., Singleton, E. S., Hill, J. R., \& Koh, M. H. (2004). Improving online learning: Student perceptions of useful and challenging characteristics. Internet and Higher Education, 7(1), 59- 70 .

Sopin, G. (2015). Students' Perceptions of Grammar Teaching and Learning in English Language Classrooms in Libya. IOSR Journal of Research \& Method in Education Ver. I, 5(2), 2320-7388. https://doi.org/10.9790/7388-05216772.

Study International. (2020). Universities shutdown: What are the online learning tools students need to know?

Tan, B. C. Y., Wei, K. K., Watson, R. T., Clapper, D. L., \& McLean, E. R. (1998). Computermediated communication and majority influence: Assessing the impact of an individualistic and a collectivistic culture. Management Science, 44(9), 1263-1278. 
Taylor, R. W. (2002). Pros and cons of online learning-a faculty perspective. Journal of European Industrial Training.

Tharuma Rajan Pillai, A. A. (2018). Social-cultural capital in youth entrepreneurship ecosystem: Southeast Asia. Journal of Enterprising Communities: People and Places in the Global Economy Social-Cultural, 1-42.

Topacio, K. N. M. (2018). Exploring the use of online educational platform in teaching writing among ESL students. Dil ve Dilbilimi Çalışmaları Dergisi, 14(1), 86-101.

Toquero, C. M. (2020). Challenges and Opportunities for Higher Education amid the COVID19 Pandemic: The Philippine Context. Pedagogical Research,5(4), em0063.https://doi.org/10.29333/pr/7947.

United Nations Department of Economic and Social Affairs (UNDESA)(1981). Definition of Youth. http://undesadspd.org/Youth.aspx

Utakrit, N. (2016). Teaching and learning attitudes, readiness, and awareness of science teachers through ICTs integration in Lao vocation and technical schools towards ASEAN education reform. Proceedings of the 4th Global Summit on Educafion, GSE 2016, 1415.

Voices of Youth. (2019). Studying at home due to coronavirus? This is how young people around the world are keeping their mood up. UNICEF.

World Health Organization (WHO). (2021). South East Asia. Adolescent Health. https://www.who.int/southeastasia/health-topics/adolescent-health.

World Economic Forum. (2020). Impact of Social Distancing on ASEAN Youth.

Wouters, P., Van Nimwegen, C., Van Oostendorp, H., \& Van der Spek, E. D. (2013). A MetaAnalysis of the Cognitive and Motivational Effects of Serious Games. Journal of Educational Psychology, 105(2), 249-265. https://doi.org/10.1037/a0031311.

Yarrow, N. (2020). COVID-19in East Asia: How the Region's Higher Education Systems are Addressing the Crisis to Adapt to the Future. Education for Global Development.

Yee, S. L. W., \& Ean, C. L. C. (2020). Malaysian private university students' perception of online discussion forums: A qualitative enquiry. Sains Humanika, 12(2).

Yusof, N. M. (2008). E-Methods in Literary Production: Integrating E-Learning In Creative Writing. 3L: Language, Linguistics, Literature, 14(1), 127-148.

Zakaria, G. A. N., Tajudeen, A. L., Nawi, A., \& Mahalle, S. (2014). Re-Engineering Values into the Youth Education System: A Needs Analysis Study in Brunei Darussalam. International Education Studies, 7(5), 15-24. 